\title{
BŪTI AR ATRODYTI? MOKSLININKO-DĖSTYTOJO VAIDMENYS AUKŠTAJAME MOKSLE
}

\author{
Dokt. Marius Daugèla \\ Edukologijos tyrimu institutas, Vytauto Didžiojo universitetas \\ Prof. habil. dr. Vilma Žydžiūnaitè \\ Edukologijos tyrimu institutas, Vytauto Didžiojo universitetas \\ DOI: https://doi.org/10.52320/svv.vOiVI.190
}

\begin{abstract}
Anotacija
Buvimas mokslininku-dèstytoju aukštajame moksle yra ne tik įsipareigojimas, bet kartu pasireiškia per konkrečią asmens veiklą. Universitete veikiantis ir dirbantis mokslinkas-dèstytojas susiduria ne tik su išoriniais faktoriais, kurie apibrèžia jo vaidmenis aukštajame moksle, bet ir su savo asmenybės subtilybėmis. Tyrimo tikslas - apžvelgti mokslinėje literatūroje išskiriamus mokslininko-dėstytojo vaidmenis, esančius aukštajame moksle, bei išskirti esminius iššūkius, kurie kyla atliekant šiuos vaidmeni. Todèl keliamas tyrimo klausimas - kokie vidiniai ir išoriniai iššūkiai kyla mokslininkųdèstytojų vaidmenims aukštajame moksle? Šio tyrimo objektas - mokslininkų-dèstytojų vaidmenys aukštajame moksle. Šiame tyrime naudota integralioji literatūros apžvalga. Pastebėta, jog buvimas mokslininku-dèstytoju universitete persipina su formaliais reikalavimais bei vidiniais asmeniniais lūkesčiais ir siekiais, kurie lemia ne tik perdegimo ar pervargimo patirtis, bet parodo ir giluminị asmens pripažinimo, palaikymo ir bendradarbiavimo lūkestị. Neatlieptas poreikis slopina mokslininko-dèstytojo entuziazmą, todèl individas atsiduria formaliuose rèmuose, kurie ji $/$ ją varžo. Formuojama tyrimo išvada, kad, siekiant būti universiteto mokslininku-dèstytoju, svarbu atitikti ne tik formalius reikalavimus, bet prasminga tapti reflektyviu ir autentišku mokslininku, veikiančiu, dirbančiu, bendradarbiaujančiu bei intelektiškai lyderiaujančiu ir internalizuojančiu moralines vertybes aukštajame moksle.
\end{abstract}

Pagrindiniai žodžiai: aukštasis mokslas, mokslininko-dèstytojo vaidmenys, universitetas.

\section{Ivadas}

Buvimas mokslininku-dėstytoju aukštajame moksle yra ne tik įsipareigojimas, bet pasireiškia per konkrečią asmens veiklą. Universitete veikiantys ir dirbantys mokslinkai-dèstytojai susiduria ne tik su išoriniais faktoriais, kurie apibrèžia jų vaidmenis aukštajame moksle, bet ir su savo asmenybès subtilybėmis. Būtent tarp visų oficialių reikalavimų bei atliekamų įsipareigojimų kartais lieka nepastebètos mokslininkų-dèstytojų asmenybès pusès, kuriose esti įvairios žmogiškos dilemos. Šios vidinès ir išorinès veiksnių sampynos iškelia poreikį matyti mokslininkus-dèstytojus aukštajame moksle kaip visybiškas, reflektuojančias asmenybes, kurios ne tik tyrinėja, bendradarbiauja, kuria, bet ir ugdo besimokančiuosius.

Ant mokslininkų-dèstytojų pečių ,gula” didžiulè atsakomybė ne tik dèl dėstymo ar publikacijų kokybės, bet ir dẻl sunkumų, iškylančių siekiant suderinti mokslininkų vaidmenis aukštajame moksle (Heng ir kt., 2020; Xu, 2017; Žydžiūnaitė, 2019). Buvimas mokslininku-dèstytoju aukštajame moksle atveria didelio streso patyrimo ar profesinio perdegimo patirtis (Azeem ir Nazir, 2008; Berg, 2001; Eacute ir Esteve, 2000; Zhong ir kt. 2009), kurios neretu atveju atspindi ir depresijos bei nusivylimo savo darbu apraiškas. Stingant kolegų, studentų, artimujų ar net draugų palaikymo bei supratimo, susiduriant su vis daugiau reikalavimų, mokslininkai-dèstytojai atsiduria savo asmenybès paribiuose. Pasilikdami vienumoje su kylančiomis problemomis mokslininkai-dèstytojai gali formuoti puikaus eksperto ịvaizdị, tačiau jie gali būti vieniši ir išgyventi sunkumus. Dialogo bei intelektinès ir moralinès lyderystès stoka aukštajame moksle (Deutsch, 2011; Macfarlane, 2011; Kwiek, 2015; Uslu ir Welch, 2016) atveria naujus iššūkius, kurie apsunkina mokslininkų-dėstytojų darbą. Šiuo tyrimu siekiama apžvelgti mokslinėje literatūroje išskiriamus mokslininko-dèstytojo vaidmenis, esančius aukštajame moksle, bei išskirti esminius iššūkius, kurie kyla atliekant šiuos vaidmeni. Todèl keliamas tyrimo klausimas - kokie vidiniai ir išoriniai iššūkiai kyla mokslininkų-dèstytojų vaidmenims aukštajame moksle? Šio tyrimo objektas - mokslininkų-dèstytojų vaidmenys aukštajame moksle. Šiame tyrime naudojama integralioji literatūros apžvalga (integrative literature review), kuria siekiama kritiškai apžvelgti ir permąstyti esančias koncepcijas bei išplètoti konkrečios temos teorini pagrindą (Snyder, 2019). 


\section{Tarp dviejų paradigmų}

Paskaitos ir jų déstymas universitete seniausias ir pirmuosius universitetus menantis būdas perteikti žinias bei ugdyti studentus. Tradiciškai i dėstytoją orientuotas studentų ugdymas, turintis gilias šaknis empirizmo ugdymo filosofijoje (Locke, 1689/1996; Hume, 1777/1993), pabrèžè, kad dėstytojas yra atsakingas už žinių perdavimą studentams. Toks ugdymas grịstas aktyviu dèstytojo ir pasyviu studento įsitraukimo modeliu (Mascolo, 2009). Šiame žinių generavimo ir perteikimo procese dèstytojai buvo centras, kaip ir i juos orientuotas mokymosi procesas, todél tradiciškai aukštajame moksle dėstytojai buvo matomi kaip autoritetai, kurie taisydavo savo studentų klaidas, perteikdavo informaciją ir retai užimdavo klausytojo poziciją (Badley ir Habeshaw, 1991). Klausytojo pozicija universitete natūraliai sukurdavo atstumą tarp dėstytojų ir studentų, dèl to studentai buvo suvokiami kaip pasyvūs besimokantieji, priimantys perteikiamą informaciją. Studentų keliami klausimai būdavo atsakomi tik dėstytojo, be kitų studentų ịtraukimo ị diskusiją (Emaliana, 2017). Diskusijos nebuvimas didino atskirtị tarp žinių teikèjų - dėstytojų ir žinių prièmèjų - studentų, todèl dèstytojas buvo (Hancock, Bray ir Nason, 2003, p. 366): a) dominuojantis, kuris sukuria ir studentams pateikia aiškias dėstomo kurso taisykles; b) struktūruojantis ir nustatantis užduotis bei jų atlikimą; c) aktyviai nurodantis ir paaiškinantis bei modeliuojantis paskaitos tikslus ir studentų dalyvavimą atliekant užduotis; d) tiesiogiai reaguojantis ị studentus bei jų užduodamus klausimus, suteikdamas grịžtamajji ryši, naudodamas raginimus ir užuominas, o jei reikia, pateikdamas teisingus atsakymus.

Universiteto dèstytojo kaip centrinès figūros dominavimas ugdymo procese formavo ir tam tikras nuostatas bei požiūrius,koks ir kaip turi atrodyti bei būti dèstytojas. Šios nuostatos bei požiūriai darė įtaką universiteto dėstytojų vaidmenims, kuriuos jie atlikdavo aukštajame moksle. Tradiciškai universiteto dėstytojas buvo matomas kaip dèstomo kurso projektuotojas (Badley ir Habeshaw, 1991; Hall, 1996), dalyko dėstytojas (Baldey ir Habeshaw, 1991; Fisher ir Hänze, 2019), darbų vadovas ir konsultantas (Hall, 1996; Badley ir Habeshaw, 1991), studentų darbu ir kurso vertintojas (Mascolo, 2009; ALRowais, 2015; Badley ir Habeshaw, 1991) bei dalyko ekspertas (Badley ir Habeshaw, 1991; Hall, 1996). Būtų galima teigti, kad šie universiteto dèstytojo vaidmenys sukuria tam tikrą požiūrị i dèstytojus, kuris lemia jog ugdymas tampa tik vienkrypčiu žinių perdavimo procesu.

Kitas svarbus dalykas, kad i dèstytoją orietuota paradigma kelia daug iššūkių, kurie „yra siejami su hierarchine pedagogika (iš viršaus $\mathfrak{i}$ apačią) ir tuo pat metu yra stiprinamas besimokančiujų pasyvumas, kuris trukdo ugdytis aukštesnio pažinimo įgūdžius“ (Otukile-Mongwaketse, 2018, 12 p.). Tokia paradigma kuria galios principus, kurie centralizuotai kontroliuoja besimokančiuosius (Cristillo, 2010). Nors pats universiteto dėstytojas gali ir neturèti intencijos savo studentus laikyti klusniais ir pasyviais klausytojais, tačiau paradigmos rèmuose tokia laikysena -yra pakankamai gaji.

Konstruktyvistinès ugdymo filosofija (Piaget, 1973/1985; Vygotsky, 1978; Kolb, 1984) išryškina i besimokantijji orientuotą paradigmą, kuri keičia ne tik studento, bet ir universiteto dèstytojo vaidmenis ugdymo procesuose. Universiteto dèstytojas iš informacijos ir žinių perteikèjo tampa besimokančiu ir bendradarbiaujančiu kartu su studentu ir kolegomis, todèl mokosi ir gilina jau turimas žinias ir sampratas (Crisol, 2011). Šị paradigmini pokyti galima iliustruoti ị dèstytoją ir besimokantiji orientuotomis paradigmomis (1 lentelè). Paradigmų pokytis ypatingai keičia ir dèstytojų vaidmenis universitete, kurie skatina bendradarbiavimą ir mokymąsi kartu. Svarbu pastebèti, kad dèstytojai, tapdami studentui pagalbininkais, pirmiausia dalijasi lyderyste, kuria skatina studentus įsitraukti i ugdymo(si) procesą bei dalintis turimomis žiniomis ir įžvalgomis (ALRowais, 2015). Toks procesas igalina tarpusavio mainus tarp universiteto déstytojų ir studentų, o šie manai universiteto déstytojams atveria galimybes ne tik būti formaliais žinių teikèjais, bet kartu mokytis ir prisidèti prie studentų augimo bei pokyčio. 
1 lentelè. Paradigminis pokytis

\begin{tabular}{|c|c|}
\hline I dèstytoją orientuota paradigma & I besimokantijị (studentą) orientuota paradigma \\
\hline $\begin{array}{l}\text { Universiteto déstytojo generuojamos žinios, perduodamos } \\
\text { studentams. }\end{array}$ & $\begin{array}{l}\text { Studentai konstruoja žinias jas rinkdami, sintetindami ir } \\
\text { integruodami. Ugdomi bendradarbiavimo, kritinio } \\
\text { mąstymo, problemų sprendimo ịgūdžiai. }\end{array}$ \\
\hline Studentai pasyviai priima informaciją. & Studentai aktyviai įtraukiami į ugdymo procesą. \\
\hline $\begin{array}{l}\text { Daugiausia dėmesio skiriama žinioms igyti, bet ne } \\
\text { kontekstams, kuriuose žinios bus naudojamos. }\end{array}$ & $\begin{array}{l}\text { Pagrindinis dèmesys skiriamas igytų žinių panaudojimui ir } \\
\text { bendradarbiavimui, kuriuo galima efektyviai spręsti } \\
\text { kylančias realaus gyvenimo problemas. }\end{array}$ \\
\hline $\begin{array}{l}\text { Universiteto dėstytojo pirminis vaidmuo pasireiškia per } \\
\text { informacijos perteikimą studentams ir jų vertinimą. }\end{array}$ & $\begin{array}{l}\text { Universiteto dėstytojo vaidmuo pasireiškia per mokymą ir } \\
\text { pagalbą studentams. Dėstytojas ir studentai vertina } \\
\text { mokymosi procesą kartu. }\end{array}$ \\
\hline Mokymas ir vertinimas yra atskirti. & Mokymas ir vertinimas yra tarpusavyje susiję. \\
\hline Vertinimas naudojamas tik mokymui stebėti. & Vertinimas naudojamas kaip pagalba mokymuisi. \\
\hline Akcentuojami teisingi atsakymai. & $\begin{array}{l}\text { Pagrindinis dèmesys yra skiriamas klausimų formulavimui } \\
\text { ir mokymuisi iš klaidų. }\end{array}$ \\
\hline Mokymasis vertinamas testais. & $\begin{array}{l}\text { Mokymasis vertinamas per studento parengtus darbus, } \\
\text { projektus, aplankus (portfolio) ir pan. }\end{array}$ \\
\hline Dėmesys sutelktas į vieną discipliną. & Ieškoma tarpdisciplininių jungčių. \\
\hline $\begin{array}{l}\text { Mokymo(si) kultūra paremta konkurencija ir } \\
\text { individualizmu. }\end{array}$ & $\begin{array}{l}\text { Mokymo(si) kultūra paremta palaikymu ir } \\
\text { bendradarbiavimu. }\end{array}$ \\
\hline Tik studentai yra matomi kaip besimokantieji. & Universiteto dėstytojas ir studentai mokosi kartu. \\
\hline
\end{tabular}
Šaltinis: sudaryta pagal Sawant ir Rizvi, 2015.

Pastebima, kad esti sąsajos tarp dėstymo metodų, kuriuos universiteto dėstytojai naudoja savo paskaitose, ir siekiamų tikslų ugymo procese (Trigwell ir Prosser, 1996):

1. I destytoja orietuota strategija siekiant perteikti informaciją. Šio perdavimo metu svarbiausias dėmuo yra faktų ir žinių perteikimas, kuriame studentas yra pasyvus klausytojas.

2. I dèstytoja orientuota strategija siekiant ugyti déstomos disciplinos suvokima. Šiame procese svarbią vietą užima universiteto dèstytojų siekis atskleisti dėstomos disciplinos konceptus ir parodyti sąsajas tarp jų.

3. Déstytoju ir studentu squeikos strategija siekiant ugdyti déstomos disciplinos suvokima. Šiame procese per universiteto dèstytojų ir studentu interakcijas yra siekiama atskleisti dèstomos displinos konceptus ir padèti rasti sąsajas tarp jų.

4. I besimokantiji (studenta) orientuota strategija siekiant, kad patys studentai formuotu savo suvokima. Šio proceso metu universiteto desstytojai siekia padèti studentams jungti jau turimas žinias bei ịūdžius su naujomis žiniomis, taip kuriant savo asmeninį suvokimą.

5. I besimokantiji (studenta) orientuota strategija siekiant, kad studentai keistu savo turimas sampratas. Sio procesu metu universiteto dèstytojai siekia padeti studentams konstruoti naujus ir perkonstruoti jau turimus suvokimus, juos kritiškai vertinant bei formuoti savo autentišką požiūrį.

Kai siekiama tik perduoti informaciją studentams, dažniausiai naudojama i dèstytoją orientuota strategija, tačiau siekiant ugdyti studentų kritini mąstymą ar suteikiant pagalbą studentams kurti asmenines autentiškas sampratas (konstruoti ir perkonstruoti turimus bei naujus suvokimus) naudojama ị besimokantiji (studentą) orientuota mokymo/si strategija.

\section{Mokslininkų-dėstytojų vaidmenys aukštajame moksle}

Aukštajame moksle veikiančio mokslininko-dėstytojo vaidmenys tiesiogiai paliečia konkretų asmenị. Mokslininkas-dèstytojas turi būti ,gerai nusimanantis savo srities specialistas, entuziastingas, savimi pasitikintis, optimistiškas, komunikuojantis, atsidavęs, smalsus, kantrus, atkaklus, norintis dirbti kartu, išradingas, gerai organizuotas, etiškas ir reflektuojantis“ (Kivunja, 2014, 38 p.). Mokslininkui reflektuojant turètų kilti klausimas: „Ar aš toks esu, ar toks atrodau?” Burroughs-Lange (1996) tyrimas atskleide keturis elementus, kurie kyla iš mokslininko-dèstytojo asmens ir daro įtaką jo vaidmenims aukštajame moksle: mokslininkų-dèstytojų suvokimas apie mokymos(si) svarbą; savo 
studentų ir kolegų suvokimas; atsakomybė už savo tyrimų sritis; atsakomybė už ir prieš savo studentus.Visi šie elementai yra tarpusavyje tampriai susiję ir persidengę bei giliai paliečia universiteto mokslininko-dèstytojo asmenybę. Profesiniame ir instituciniame kontekste veikiantis mokslininkasdèstytojas yra ne tik kaip atskira asmenybè, bet kartu atliekaįvairius vaidmenis, kurie būdingi aukštajam mokslui. Universiteto mokslininkas-dèstytojas yra matomas kaip informacijos teikejjas, sektinas pavyzdys, pagalbininkas, vertintojas, planuotojas ir/ar išteklių kūrejjas (Harden ir kt., 2000).

Būti informacijos teikejju reiškia praktines ir teorines veiklas, kurios tiesiogiai yra susijusios su studentais. Šią mintị papildo ALRowais (2015) įžvalgos, kad šalia informacijos perteikimo universiteto mokslininkas-dèstytojas yra kaip studentų skatintojas ịgalinti savo gebejjimus ir ịūdžius bei studentų pasiekimų vertintojas, ugdymo turinio organizatorius bei dalyvis šiame ugdymo procese. Fisher ir Hänze (2019) teigimu, mokymo/si organizavimas ir dalyvavimas ugdymo procese aukštajame moksle įtraukia mokslininką-dèstytoją ị ieškojimą interaktyvių mokymosi būdų, domèjimąsi studentų rūpesčiais bei jų motyvavimą sąmoningam mokymuisi.

Būti sektinu pavyzdžiu aukštajame moksle visuomet yra iššūkis, nes ne tik studentų ar kolegų, bet ir visuomenès dèmesys gali krypti ị konkretų mokslininką-dèstytoją. Anot Macfarlane (2011), būti sektinu pavyzdžiu yra tiesiogiai susiję su intelektine ir moraline lyderyste tiek aukštajame moksle, tiek visuomenejje. Pastebima, kad intelektinė lyderystė universitete pasireiškia per ,parodytą išskirtinę savo disciplinos ekspertizę tarptautiniu ir nacionaliniu mastu, remiantis mokslo pasiekimais bei metodologines, pedagogines ir savo atstovaujamos disciplinos žinias, bei šių dalykų išmanymą, santykius su kolegomis, kai siekiama padèti ir plètoti tiek savo, tiek kitų akiratị bei suvokimą" (Uslu ir Welch, 2016, p. 572).

Lyderystė aukštajame moksle apima ne tik mokslininko-dèstytojo asmenybę ir veiklą, bet ir santykius su kolegomis bei studentais. Yra išskiriama, kad mokslininko intelektinès lyderystès igyvendinimas atsiveria per dėstymo ir mokslo tyrimų sritis aukštajame moksle, todèl būti lyderiu dèstymo srityje reiškia gebėti integruoti naujas idejas „nuo studijų dalyko ar modulio sukūrimo ir igyvendinimo, dirbant su studentais paskaitose, seminaruose, praktiniuose užsièmimuose ir jiems rengiant ịvairių tipų studijų darbus, iki padalinyje dirbančių mokslininkų mokymų tam, kad būtų perimta inovatyvi patirtis“ (Žydžiūnaitè, 2019, 89 p.). Šią poziciją papildo ALRowais (2015) įžvalga, jog universiteto mokslininkas-dėstytojas yra žmogiškasis išteklius. Idejjų generavimas ir igyvendinimas bei ekspertizè reikalauja dėstytojo-mokslininko laiko sąnaudų ir gyvybinių (sveikatos) išteklių. Tuo tarpu mokslininko intelektinė lyderystė tyrimuose pasireiškia per paramą ir pagarbą mokslininkams kaip šios lyderysytės pavyzdžiams bei siekant pateikti mokslu grịstus įrodymus (Žydžiūnaitė, 2019). Universiteto mokslininko-dėstytojo lyderystė skleidžiasi akademiniais vaidmenimis, kurie skatina ne tik asmens atsakomybę, bet ir akademinès personalizuotos individualybės/asmenybès tapsmą.

Déstytojo-mokslininko buvimas sektinu pavyzdžiu aukštajame moksle grindžiamas ne tik atliktais darbais, bet pagarba mokslui, studentams bei kolegoms, vadovavimusi aukštomis moralinėmis vertybėmis, kurias universiteto mokslininkas-dèstytojas internalizuoja per savo praktiką ir asmeninę refleksiją.

\section{Veiksniai, darantys įtaką mokslininko-dèstytojo vaidmenims aukštajame moksle}

Mokslininko-dèstytojo veikla universitete yra veikiama įvairių veiksnių, kurie daro ịtaką jo vaidmenims. Anot ALRowais (2015), universiteto mokslininko-dèstytojo vaidmenims ịtaką daro jo asmenybè, vertybės ir įsitikinimai, universiteto aplinka (mokymosi aplinka ir kontekstai, informacinès komunikacinès technologijos) bei institucinè kultūra (teisès ir ịsipareigojimai, rašytinès ir nerašytinès taisyklès). Universiteto mokslininko-dèstytojo vaidmenims itaką daro vidiniai ir išoriniai veiksniai, kurie padeda ịgyvendinti procesus, bet kartu kelia iššūkius. Vienu iš pagrindiniu veiksnių mokslininkųdèstytojų vaidmenims igyvendinti daro jų savimoné (Kivunja, 2014). Savimonè universiteto mokslininko-dèstytojo asmenybeje inkorporuoja ne tik vertybes, ịsitikinimus, bet ir savęs suvokimo, savivertès, savikontrolès, savigarbos, savirefleksijos, savęs pažinimo ir kt. konceptus (Flavian, 2016). Aukštosios mokyklos dèstytojų-mokslininkų savimonès ugdymas padeda universiteto mokslininkamsdèstytojams atrasti darną tarp vidinių ir išorinių iššūkių, kurie kyla jų darbe. Anot Blaškov ir kt. 
(2014), vienu iš svarbiausių saviugdos metodu tampa savirefleksija, kuri padeda mokslininkuidèstytojui rasti vidinę darną bei suteikia galimybę objektyviai ir kritiškai pažvelgti, ịvertinti save, apmąstyti savo perteikiamas žinias studentams ir kolegoms. Vadinasi, universiteto mokslininkodèstytojo savirefleksija yra pamatas akademiniame kelyje.

Spartūs visuomenès ir aukštojo mokslo pokyčiai atveria naujus iššūkius, su kuriais susiduria mokslininkai-dèstytojai dirbdami universitete (Eacute ir Esteve, 2000): didejantys reikalavimai ir darbo krūviai dėstytojams; darbas multikultūrinejje aplinkoje; švietimo socialinès vertès pasikeitimas; socialinè švietimo sistemos kritika ir mokslininko socialinio statuso bei vertès smukimas. Universitete mokslininkas-dèstytojas yra pasidalinęs tarp dèstymo, tyrimų bei administracinio darbo, o didèjanti biurokratija trukdo susikoncentruoti i pagrindinius ịsipareigojimus (Berg, 2001). Mokslininkųdėstytojų darbą aukštajame moksle labiausiai sunkina administracinio darbo krūviai, darbe patiriamas stresas (pasidalinimas tarp dėstymo ir tyrimu veiklu), sunkiai randamas balansas tarp asmeninio ir darbinio kontekstų, o dèl to iškyla minčių palikti akademinị kelią (Darabi ir kt., 2016).

Nuo XX a. 8-ojo dešimtmečio vis dažniau pedagoginèje mokslinèje literatūroje apibūdinant mokslininkų-dèstytojų darbą universitete atsiranda sąvokos kaip stresas ir perdegimas (Eacute ir Esteve, 2000). Streso ir perdegimo patyrimas tiesiogiai veikia ir kenkia univesiteto mokslininkųdèstytojų sveikatai (Berg, 2001). Su išgyvenamu perdegimu ir stresu smunka mokslininko-dèstytojo moralè, entuziazmas bei pasitenkinimas savo veikla, o tai veda prie cinizmo ir/ar depresijos apraiškų (Azeem ir Nazir, 2008; Zhong ir kt. 2009). Perdegimas paliečia mokslininko-dèstytojo asmeninio ir profesinio gyvenimo dimensijas, kurios yra susijusios. Universiteto mokslininkų-dèstytojų perdegimą lemia santykių gausa su studentais, kolegomis ir administracija (Blix ir kt., 1994), kylantys iššūkiai suderinti mokslininko ir dèstytojo vaidmenis (Xu, 2017; Žydžiūnaitė, 2019; Heng ir kt., 2020), šeimos, draugų ir/ar kolegų palaikymo trūkumas (Lei ir kt. 2020).

Mokslininko-dèstytojo darbas reikalauja didelio psichologinio kapitalo, kuri sudaro „saviveiksmingumas, optimizmas, gebejimas greitai atkurti fizines ir dvasines jègas bei viltis“ (Heng ir kt., 2020, 1350 p.). Šios psichologinio kapitalo savybès suteikia universiteto mokslininkui-dèstytojui jègų sumažinti arba išvengti perdegimo galimybių taip išlaikant ịsipareigojimų ir veiklų stabilumą aukštajame moksle (Luthans ir kt., 2004).

Mokslinejje literatūroje kalbama apie universiteto mokslininkų-dėstytojų bendradarbiavimą ir pagalbą vienikitiems (Wolgast ir Fisher, 2017; Deutsch, 2011; Bahramzadeh ir Khosroabadi, 2012). Galima pastebėti tarp akademinių kolegų tvyrančią konkurenciją arba nesusikalbejjimą, kuris kyla tarp skirtingų kartų mokslininkų-dėstytojų, dirbančių universitete (Kwiek, 2015). Dèl to atsiranda skirstymas mes ir jie arba kaip buvo anksčiau ir yra dabar. Taigi, atsiranda skirtis tarp jaunosios mokslininkų-dėstytojų kartos, kuri yra labiau kosmopolitiška ir didesni dėmesį skiria tarptautiškumui, bei vyresniosios mokslininų-dėstytojų kartos, kuri labiau skiria dèmesį lokaliam, nacionaliniam kontekstui. Iš šios skirties kyla įtampa abiems dirbančių mokslininkų-dėstytojų kartoms, kuri veda ị konkurencijos atsiradimą bei abipusi neužtikrintumą dèl darbo etatų aukštojoje mokykloje (Kwiek, 2015). Norint, kad universitetas veiktų veiksmingai, yra svarbus žinių dalijimosi tarp ịvairų kartų mokslininkų-dėstytojų faktorius (Bahramzadeh ir Khosroabadi, 2012). Tai reiškia, kad skirtingų kartų dialogas bei patirties, gebèjimų, žinių sklaida tarpusavyje užmezga dialogą, kuris yra būtinas mokslininko-dėstytojo veikloms aukštajame moksle.

\section{Išvados}

Buvimas mokslininku-dèstytoju aukštajame moksle persipina su formaliais reikalavimais ir vidiniais norais, siekiais bei intencijomis, kurie atveria ne tik perdegimo ar pervargimo patirtis, bet kartu parodo gilumini asmens pripažinimo, palaikymo ir bendradarbiavimo siekị bei poreikị. Neatlieptas poreikis mažinamokslininko-dèstytojo entuziazmą ir spaudžia ji $\mathfrak{j}$ ją i formalius rèmus. Siekiant aukštojo mokslo erdvèje būti mokslininku-dèstytoju, svarbu ne tik atitikti formalius reikalavimus, bet internalizuojant aukštas moralines vertybes tapti reflektyviu ir autentišku asmeniu, veikiančiu, bendradarbiaujančiu bei intelektiškai lyderiaujančiu aukštajame moksle.

Konceptualusis tyrimas atskleidžia, kad aukštosios mokyklos dėstytojas-mokslininkas susiduria su įvairiais vaidmenimis ir iškylančiomis kolizijomis juos atlikti. Mokslininkai suvokia, kad vienu 
metu viską idealiai padaryti, atlikti yra neįmanoma misija. Kasdienis etinių dilemų išgyvenimas dèl buvimo ir atrodymo, kuriam įtaką daro reikalavimų vaidmenims aukštamaje moksle gausa, kelia dileminius, moralinius, etinius, ekspertinius ir žmogiškuosius klausimus, kurių išgyvenimas ir sprendimai kol kas tèra tik mokslininko-dèstytojo asmeninis reikalas. Tai būdinga tarptautiniam ir nacionaliniam aukštojo mokslo kontekstams.

\section{Literatūra}

1. ALRowais, A. (2015). Roles of a teacher in Colleges of Education. International Journal of Technology and Inclusive Education, 4(2), 654-660.

2. Azeem, S. M., \& Nazir, N. A. (2008). A Study of Job Burnout among University Teachers. Psychology and Developing Societies, 20(1), 51-64.

3. Badley, G., Habeshaw, T. (1991). The Changing Role of the Teacher in Higher Education. Journal of In-Service Education, 17(3), 212-218.

4. Bahramzadeh, H \& Khosroabadi, S. (2012). The relationship between organizational commitment and knowledge sharing: A case study of university employee cooperation. Management Science Letters, 2(7), 2661-2666.

5. Berg, E. (2001). To be or not to be - a lecturer in higher education in Sweden. International Journal of Sociology and Social Policy, 21(11/12), 57-74.

6. Blašková, M., Blaško, R., Jankalová, M., Radoslav, J. (2014). Key Personality Competences of University Teacher: Comparison of Requirements Defined by Teachers and/Versus Defined by Students. Procedia - Social and Behavioral Sciences, 114, 466-475.

7. Blix, A. G., Cruise, R. J., Mitchell, B. M., \& Blix, G. G. (1994). Occupational stress among university teachers. Educational Research, 36(2), 157-169.

8. Burroughs-Lange, S. G. (1996). University Lecturers' Concept of their Role. Higher Education Research \& Development, 15(1), 29-50.

9. Crisol, E. (2011). Student and teacher: new roles in the university. Journal for Educators, Teachers and Trainers, 2 (1), 84-91.

10. Cristillo, L. (2010). Struggling for the center: Teacher-centered vs. learner-centered practices in Palestinian higher education. Higher Education and the Middle East, 2, 37-40.

11. Darabi, M., A. Macaskill, and L. Reidy. (2017). A Qualitative Study of the UK Academic Role: Positive Features, Negative Aspects and Associated Stressors in A Mainly Teaching-focused University. Journal of Further and Higher Education, 41(4), 566-580.

12. Deutsch, M. (2011). Cooperation and competition. In P. T. Coleman (Ed.), Conflict, interdependence, and justice. New York: Springer.

13. Eacute, J., \& Esteve, M. (2000). The Transformation of the Teachers' Role at the End of the Twentieth Century: New challenges for the future. Educational Review, 52(2), 197-207.

14. Emaliana, I. (2017). Teacher-centered or student-centered learning approach to promote learning? Jurnal Sosial Humaniora, 10(2), 59-70.

15. Fischer, E. \& Hänze, M. (2019). How do university teachers' values and beliefs affect their teaching? Educational Psychology, 40(3), 296-317.

16. Flavian, H. (2016). Towards teaching and beyond: Strengthening education by understanding students' self-awareness development. Power and Education, 8(1), 88-100.

17. Hall, C. (1996). Key Teaching Roles of a University Lecturer and their Integration into the Quality Systems of a New Zealand University. Assessment \& Evaluation in Higher Education, 21(2), 109120.

18. Hancock, D. R., Bray M., \& Nason, S. A. (2003). Influencing university students' achievement and motivation in a technology course. The Journal of Educational Research, 95, 365-372.

19. Harden, R. M, and Crosby, J. R. (2000). AMEE Education Guide No 20: The good teacher is more than a lecturer - the twelve roles of the teacher. Medical Teacher, 22(4), 334-347. 
20. Heng, S., Yang, M., Zou, B., Li, Y., \& Castaño, G. (2020). The mechanism of teaching-research conflict influencing job burnout among university teachers: The roles of perceived supervisor support and psychological capital. Psychology in the Schools, 57(9), 1347-1364.

21. Hume, D. (1777/1993). An Inquiry Concerning Human Understanding. Indianapolis, IN: Hackett.

22. Kivunja, C. (2014). Innovative pedagogies in higher education to become effective teachers of 21st century skills: Unpacking the learning and innovations skills domain of the new learning paradigm. International Journal of Higher Education, 3(4), 387-398.

23. Kolb, D.A. (1984) Experiential Learning: Experience as the Source of Learning and Development. Englewood Cliffs, NJ: Prentice-Hall.

24. Kwiek, M. (2015). Academic generations and academic work: patterns of attitudes, behaviors, and research productivity of Polish academics after 1989. Studies in Higher Education, 40(8), 13541376.

25. Lei, W., Li, J., Li, Y., Castaño, G., Yang, M., \& Zou, B. (2020). The boundary conditions under which teaching-research conflict leads to university teachers' job burnout. Studies in Higher Education, 46(2), 1-17.

26. Locke, J. (1689/1996). Essay Concerning Human Understanding. Indianapolis, IN: Hackett.

27. Luthans, F., Luthans, K. W., \& Luthans, B. C. (2004). Positive psychological capital: Beyond human and social capital. Business Horizons, 47(1), 45-50.

28. Macfarlane, B. (2011). Professors as intellectual leaders: formation, identity and role. Studies in Higher Education, 36(1), 57-73.

29. Mascolo, M. (2009). Beyond Student-Centered and Teacher-Centered Pedagogy: Teaching and Learning as Guided Participation. Pedagogy and the Human Sciences, 1(1), 3-27.

30. Otukile-Mongwaketse, M. (2018). Teacher centered dominated approaches: Their implications for today's inclusive classrooms. International Journal of Psychology and Counselling, 10(2), 11-21.

31. Piaget, J. (1973). To Understand is to Invent: The Future of Education. New York: Grossman.

32. Piaget, J. (1985). Equilibration of Cognitive Structures. Chicago, IL: University of Chicago Press.

33. Sawant, S. P., P., Rizvi, S. (2015). Study of passive didactic teacher centered approach and an active student-centered approach in teaching anatomy. International Journal of Anatomy and Research, 3(3), 1192-1197.

34. Snyder, H. (2019). Literature Review as a Research Methodology: An Overview and Guidelines. Journal of Business Research, 104, 333-339.

35. Trigwell, K., \& Prosser, M. (1996). Congruence between intention and strategy in university science teachers' approaches to teaching. Higher Education, 32(1), 77-87.

36. Uslu, B., \& Welch, A. (2016). The influence of universities' organizational features on professorial intellectual leadership. Studies in Higher Education, 43(3), 571-585.

37. Vygotsky, L. (1978). Mind in Society. Cambridge: Harvard.

38. Wolgast, A., \& Fischer, N. (2017). You are not alone: colleague support and goal-oriented cooperation as resources to reduce teachers' stress. Social Psychology of Education, 20, 97-114.

39. Xu, L. (2017). Teacher-researcher role conflict and burnout among Chinese university teachers: a job demand-resources model perspective. Studies in Higher Education, 44(6), 1-17.

40. Zhong, J., You, J., Gan, Y., Zhang, Y., Lu, C., \& Wang, H. (2009). Job stress, burnout, depression symptoms, and physical health among Chinese university teachers. Psychological Reports, 105(3 Pt 2), 1248-1254.

41. Žydžiūnaitè, V. (2019). Mokslininko intelektine lyderystė aukštajame moksle: poreikis, veiksniai ir iššūkiai. Kaunas: Vytauto Didžiojo universitetas. 


\title{
TO BE OR TO APPEAR? ROLES OF RESEARCHER AND TEACHER IN HIGHER EDUCATION
}

\author{
PhD student Marius Daugèla, Educational Research institute, Vytautas Magnus university \\ Prof. Vilma Žydžiūnaitè, Educational Research institute, Vytautas Magnus university
}

\begin{abstract}
Summary
Being a researcher-teacher in higher education intertwines with formal requirements and internal desires, aspirations and intentions, which open up not only the experience of burnout or overwork, but at the same time show the deep aspiration and need for personal recognition, support and cooperation. The unresolved need quenches the enthusiasm of the researcher-teacher and pushes him / her into formal frames. In order to be a researcher-teacher in the higher education space, it is important not only to meet formal requirements, but also to become a reflective and authentic person who acts, collaborates and intellectually leads in higher education by internalizing high moral values.

Being a teacher and researcher in higher education is not only a commitment, but at the same time manifests itself through specific personal activities. The scientist as researcher and teacher working at a university is confronted not only with the external factors that define his / her roles in higher education, but also with the subtleties of his / her personality. The question is therefore: "What are the internal and external challenges for the roles of scientists as researchers and teachers in higher education?" The aim of the study was to review the roles of the scientist through teaching and researching paradigms in higher education distinguished in the scientific literature and to single out the essential challenges that arise in relation to these roles.

The dominance of the university teacher as a central figure in the educational process has also formed certain attitudes about what and how a university teacher should look and feel. These attitudes influenced the roles of university teachers in higher education. Traditionally, a university teacher has been seen as a course designer, a subject lecturer, a supervisor, a consultant, an evaluator of student work and the course, and a subject expert. It could be argued that these roles of university teacher create a certain attitude towards scientists-teachers, which leads to education becoming only a one-way process of knowledge transfer. Another important point is that the university teacher-oriented paradigm poses many challenges that are linked to hierarchical pedagogy (top-down) and at the same time reinforce learner passivity that hinders the development of higher cognitive skills. Such a paradigm creates principles of power that centrally control students. Although the university teacher him/herself may not have the intention to consider his / her students as obedient and passive listeners.

The constructivist philosophy of education highlights a learner-centered paradigm that changes the roles of not only the student but also the university teacher in educational processes. A university teacher from an information and knowledge transferor becomes a learner and collaborates with students and colleagues, thus learning and deepening existing knowledge and concepts.

Being a role model in higher education is always a challenge, as not only students or colleagues, but also the public can focus on a specific researcher-lecturer. Being a role model is directly related to intellectual and moral leadership in both higher education and society. It is observed that intellectual leadership in the university manifests itself through demonstrated exceptional expertise in its discipline internationally and nationally, based on scientific achievements and methodological, pedagogical and knowledge of the discipline represented, as well as knowledge of these subjects, relationships with colleagues to help and develop both their, and the horizons and perceptions of others.

The higher education researchers and teachers in one role are faced with various roles and emerging conflicts and they need to perform this complex role, and to solve emerging issues. Scientists realize that to do everything ideally at once is impossible. The daily experience of ethical dilemmas due to presence and appearance, which is influenced by the abundance of requirements for roles in higher education, raises dilemmas, moral, ethical, expert and human issues.
\end{abstract}

Keywords: higher education; researcher-teacher roles; university. 